\title{
INVESTIGATING LOW-CRESTED BREAKWATER PERFORMANCE FOR THE DESIGN OF THE NEW ORLEANS MUNICIPAL YACHT HARBOR
}

\author{
Kevin Hanegan, Moffatt \& Nichol, New Orleans, khanegan@moffattnichol.com \\ Adrian Pearson, Moffatt \& Nichol, New Orleans apearson@moffattnichol.com \\ Chris Williams, Moffatt \& Nichol, Baton Rouge Iwilliams@moffattnichol.com
}

\section{INTRODUCTION}

The New Orleans Municipal Yacht Harbor (MYH) is located on the south shore of Lake Pontchartrain, 6 miles north of downtown New Orleans. The harbor was damaged during Hurricane Katrina in 2005, and recent city planning efforts have proposed reconstruction of the harbor interior. Moffatt \& Nichol led the design, including the hydrodynamic study which established the marine design criteria. The site is exposed to high surge events which can inundate the harbor's broad, low-crested earthen breakwater and allow waves to transmit directly into the interior (see Figure 1).

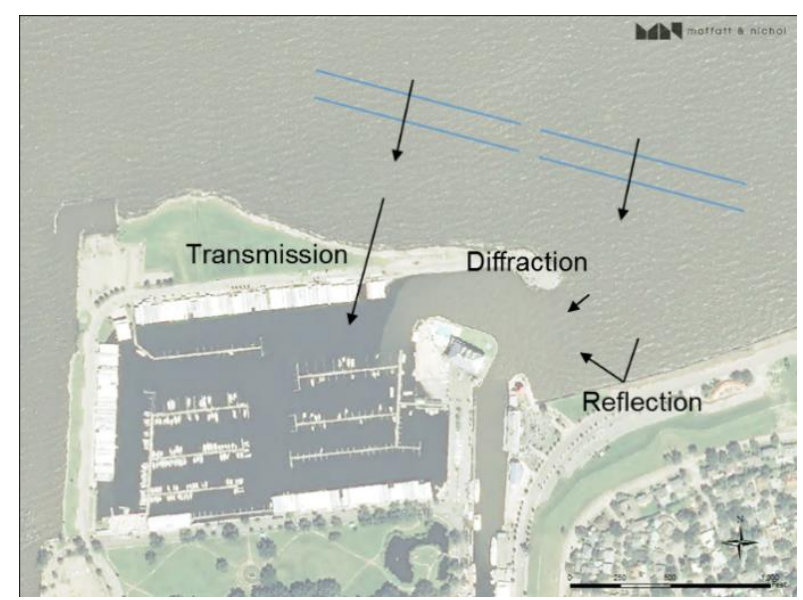

Figure 1: Wave Penetration Patterns at New Orleans Municipal Yacht Harbor

\section{MYH WAVE EXPOSURE}

The site is well-protected during normal, operational conditions: it has a low mean tidal range $(0.51-\mathrm{ft})$ over which the breakwater has adequate freeboard $(3.2-\mathrm{ft}$ at $\mathrm{MHW})$; wave heights are small $\left(\mathrm{H}_{\mathrm{s}}=2.7-\mathrm{ft}\right.$ at 1-year return-period); and the entrance channel is protected from the dominant wave direction. Operational waves propagate into the harbor through the entrance due to the combined effects of diffracted waves around the head of the breakwater and reflected waves from the stepped face of the Lakeshore Drive seawall . Extreme conditions, however, can bring high surges which inundate the breakwater and allow waves to transmit directly into the interior. The on-site NOAA tide gauge and post-Katrina FEMA high-water marks indicate that the breakwater has been submerged 6 times in the past 11 years; the maximum water level was during Hurricane Katrina, where the breakwater crest was submerged under an average water depth of 8.1-ft.

\section{MODELING WAVE TRANSMISSION}

Extreme level event (50- to 100 - yr return period) wave and surge conditions at a point 0.5 miles offshore of the MYH were taken from the USACE study developing design levee elevations for the New Orleans vicinity (US Army Corps of Engineers, 2014). To determine the associated wave conditions inside the harbor, a local
MIKE-21 Boussinesq Wave (BW) model was used to model the transmission and propagation. This model was chosen due to its accurate diffraction-reflection formulation and ability to include wave transmission, which are key factors in simulating wave agitation of the harbor.

During extreme events, diffracted and reflected waves can enter the harbor through the entrance. Due to the significant surge, the breakwater is inundated and additional wave energy enters the harbor through transmission of waves over the breakwater. The process of wave transmission is complex and difficult to reproduce numerically. Instead, empirically-derived analytical equations were used to estimate the transmission coefficient for waves impacting the breakwater. The breakwater was then implemented as an area of reduced porosity (increased energy dissipation) corresponding to the subaerial limits of the breakwater, with the porosity value adjusted so that the computed transmission in the model matched the analytically- determined value. Guidance on appropriate transmission values was obtained from the recently updated EurOtop Manual (Van der Meer, et al., 2016). With this modeling approach, the combined effects of transmission, diffraction, and reflection on design waves were simulated for varying offshore incidence angles. Still, sensitivity tests showed transmission to be the dominant factor contributing to high wave heights in the harbor interior.

\section{IMPROVING PROTECTION}

An additional preliminary investigation of potential breakwater improvements was performed based on the available empirical formula. With a limited range of applicability, the equations were used to qualitatively evaluate effectiveness of various breakwater improvements on reducing interior wave heights. Crest freeboard was found to be the most important parameter for reducing overtopping and transmission.

\section{CONCLUSIONS}

The unique exposure of the MYH to high extreme waves transmitted over a broad, low-crested breakwater led to the use of an innovative, hybrid modeling technique to derive design wave conditions. Augmented with empirical equations for transmission, a Boussinesq model was used to model wave penetration from all applicable modes as well as the spatial variability in wave parameters within the harbor so that appropriate design criteria could be applied.

\section{REFERENCES}

Van der Meer, et al. (2016) Manual on wave overtopping of sea defences and related structures.

US Army Corps of Engineers. (2014). Elevations for Design of Hurricane Protection Levees and Structures, Lake Pontchartrain and Vicinity, West Bank and Vicinity, New Orleans to Venice, Louisiana Project. 